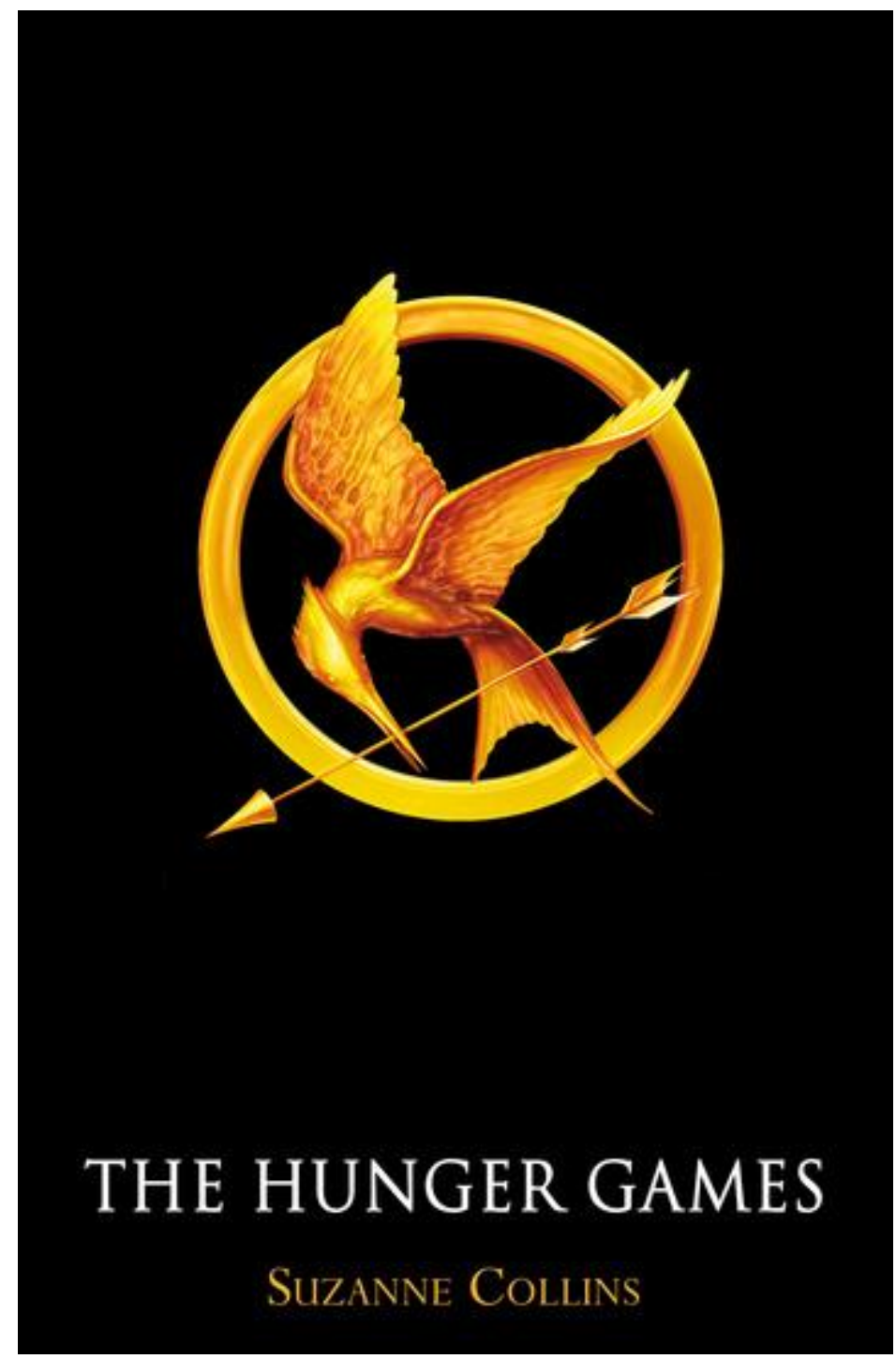

\title{
Review: The hunger games by Suzanne Collins
}

COLLINS, S. Hunger Games. $1^{\text {st }}$ edition. New York: Scholastic Press, 2008.

Karla VOLLKOPF*

Resumo: Esta resenha tem como objetivo analisar e descrever alguns dos assuntos principais tratados no enredo da obra 'Hunger Games', de autoria da escritora norte-americana Suzanne Collins. Nesta serão examinados parte dos problemas pós-apocalípticos e distópicos ocasionados no período pós-guerra descrito no livro, como fome, pobreza, doença, opressão governamental, perda de identidade, assassinato, tortura, o poder da mídia e sua

\footnotetext{
* Graduanda do curso Letras-Inglês na Universidade Federal de Santa Catarina (UFSC). E-mail: karla_vollkopf@hotmail.com
} 
possibilidade de controle mental e político, feminismo, entre outros. A resenha também tenta explorar as origem das ideias que podem ter influenciado a criação desta obra literária, assim como comparar suas similaridades com outras obras previamente publicadas por outros escritores do mundo literário. Em adição, são também examinados certos critérios narrativos relevantes escolhidos pela autora.

Palavras-chave: Distopia. Opressão governamental. Pós-guerra. Controle da Mídia. Tirania.

\begin{abstract}
The object of this review is to analyse and describe some of the main issues presented in the plot of the book Hunger Games, written by the North-American author Suzanne Collins. This review will examine some of the post-apocalyptical and dystopical problems resulting from the post-war period described in the book, such as hunger, poverty, disease, government's oppression, lost of identity, murder, torture, the power of media and its possible mental and political control, feminism, among others. This review will also try to explore the origins of the ideas that may have influenced the creation of this literary work, and compare its similarities with other works previously published by other authors in the literary world. In addition, certain relevant narrative criteria chosen by the author will be examined.
\end{abstract}

Hundreds of books out there feature many different social problems, such as poverty, starvation, the effects of war, and oppressing governments. The Hunger Games also features such issues, but in a way no other book has ever done so before.

The Hunger Games is a Young adult novel by American writer Suzanne Collins, and was originally published by Scholastic in the United States on September 14th, 2008. It was then translated into over 26 languages, and publishing rights have been sold in over 38 territories. The novel is the first in a trilogy, followed by Catching Fire (2009) and Mockingjay (2010). A film adaptation, directed by Gary Ross and co-written and co-produced by Collins herself, was released in 2012. Shortly after the release of the movie was announced, the trilogy joined the list of Banned Books, coming in at \#3 on the list. The wildly popular 'Hunger Games' trilogy joined such perennial favorites as 'To Kill a Mockingbird' and 'Brave New World,' the latter of which was published 80 years ago.

Collins was inspired to start writing the trilogy while channel surfing between reality TV programming and actual war coverage. She admits to a significant influence from the Greek myth of Theseus and the Minotaur. The myth tells how in punishment for past deeds, Athens periodically had to send seven youths and seven maidens to Crete, where they were thrown in the Labyrinth and devoured by the monstrous Minotaur. Set in a miserable future, Hunger Games joins a growing wave in the Market of best-sellers: that of the dystopian/anti-utopian and post-apocalyptic novels. The Hunger Games takes place in a nation known as Panem, established in North America after the destruction of the continent's civilization by an 
unknown apocalyptic event. The nation consists of the wealthy Capitol and twelve surrounding, poorer districts, united under the Capitol's control.

As punishment for a past rebellion against the Capitol, in which a 13th district was destroyed, one boy and one girl between the ages of 12 and 18 from each district are selected by an annual lottery to participate in the Hunger Games, an event in which the participants (or "tributes") must fight to the death in an outdoor arena controlled by the Capitol, until only one individual remains. The story is narrated by 16-year-old Katniss Everdeen, a girl from District 12 who volunteers for the 74th annual Hunger Games in place of her younger sister, Primrose. The male tribute chosen from District 12 is Peeta Mellark, a former schoolmate of Katniss who once gave her bread from his family's bakery when her family was starving.

The Hunger Games tackles issues like severe poverty, starvation, tyrannical oppression, economical contrast, and the effects of war, among others. The main themes are government control, propaganda and personal independence. Collins criticizes a society that cares more about the spectacle of The Hunger Games than about the lives lost to it, in a disturbingly wellportrayed new version of 'Bread and Circuses' (from Latin: panem et circenses). In fact, the name of the country, Panem, originates from the latin expression that describes a populace that no longer values civic virtues and the public life. It connotes the triviality and frivolity that is strongly present throughout the book. The thematic of Collins' books have been compared to other famous literary works, such as George Orwell's 1984's 'Big Brother', Koushun Takami’s Battle Royale, and even Shakespeare's Julius Caesar.

The book is organized in 27 chapters, but divided into three main parts: 'The Tributes', that goes from chapter 1 to 9, 'The Games', found in chapter 10 to 18 , and the third and last part, named 'The Victors', that reaches from chapter 19 to 27. The narrative of the book presents readers with logical and chronological sequences, and natural and transparent language, which makes use of many figures of speech, favoring metaphors, prosopopoeia, and oxymorons, among countless others. The main character, our heroine Katniss Everdeen, is the representation of the post-modern female. She goes against most stereotypes by being portrayed as a strong, smart, gun-wielding, alpha provider. But, at the same time, she is an attractive, maternal adolescent, forced to mature into the roles of both mother and father due to various circumstances. 
The Hunger Games is like a ride on a -terrifyingly- exciting roller-coaster. It manages to bring out every single emotion from its readers. We get to meet the characters and their personal dramatic pasts, which starts to create a connection, and when we least expect it... we find ourselves really caring about them. Collins makes us care for all of her fictional characters, even the 'bad guys', once we get to know them better. It is impossible not to just lose yourself in her world. When you start to think that maybe all is lost, the events take on an unexpected turn and we get what we want... only to find out we never really had it from the start. It's a highly unnerving, dizzying and strongly addicting read.

Even if I did not agree with some of the decisions the main leads made, and found some parts to be more violent than we usually expect from a Young Adult book, The Hunger Games made for an absolutely amazing read. There is never a dull-moment and it is impossible to put this book down. It is highly advisable that you acquire the other volumes of the series, for you will not want to stop until you have read it all.

\section{Sources:}

Biography of Suzanne Collins. Available at: <http://suzannecollinsbooks.com/bio.htm>. Acesso em 20 de maio de 2012.

COLLINS, S. Hunger Games. $1^{\text {st }}$ edition. New York: Scholastic Press, 2008.

FERREIRA, A. C.; SOUZA GROSSI, Y. de. A narrativa na trama da subjetividade: perspectivas e desafios. Economia \& Gestão, Belo Horizonte, v. 2, n. 3, p. 120-134, 2002. GANCHO, C. V. Como Analisar Narrativas. $7^{\text {a }}$ edição. São Paulo: Ática, 2002.

KJOS, Berit. 'Hunger games' the orwellian theme behind the movie. Crossroad, March 26. 2012. Available at: 〈http://www.crossroad.to/articles2/2012/3-hunger-games-movie.htm>. Accessed on: Sep 282012. MESQUITA, S. N. de. O enredo. $4^{\text {a }}$ edição São Paulo: Ática, 2006.

SAMPSON, Mike. 'The hunger games' joins the top 10 "banned books" list. Screen Crush, April 10, 2012. Available at: 〈http://screencrush.com/the-hunger-games-banned/ >. Accessed on: Sep 282012. 